\title{
INFLUENCE OF FIRE AND JUNIPER ENCROACHMENT ON BIRDS IN HIGH-ELEVATION SAGEBRUSH STEPPE
}

\author{
Anna C. Noson ${ }^{1,3}$, Richard A. Schmitz ${ }^{1}$, and Richard F. Miller ${ }^{2}$
}

\begin{abstract}
We examined relationships between high-elevation sagebrush (Artemisia spp.) steppe habitats altered by prescribed fire and western juniper (Juniperus occidentalis) encroachment on breeding distributions of Brewer's Sparrows (Spizella breweri), Vesper Sparrows (Pooecetes gramineus), Green-tailed Towhees (Pipilo chlorurus), and Sage Thrashers (Oreoscoptes montanus) on Steens Mountain in southeastern Oregon. In 2000 we conducted fixed-radius point count surveys at 172 sites encompassing burned and unburned sagebrush habitat and a range of juniper densities. For each bird species we developed habitat models using local variables measured in the field and landscape variables derived from remotely sensed data. Akaike's Information Criterion $\left(\mathrm{AIC}_{c}\right)$ was used to select the best-approximating model from a suite of a priori candidate models. Brewer's Sparrows, Sage Thrashers, and Green-tailed Towhees were positively related to increasing local sagebrush cover or percent sagebrush in the landscape, whereas Vesper Sparrows were negatively associated with sagebrush cover and positively related to increases in sagebrush fragmentation at local and landscape scales. Including a measure of juniper encroachment substantially improved models for all species in the analysis. Green-tailed Towhees showed a curvilinear response to the amount of juniper in the landscape. All other species showed a strong negative relationship with juniper. Our results indicate that, although changes in sagebrush habitat associated with fire had a negative influence on sagebrush birds, juniper encroachment due to fire suppression also impacted this high-elevation sagebrush bird community.
\end{abstract}

Key words: birds, habitat relationships, juniper encroachment, landscape, prescribed fire, sagebrush steppe, Oregon.

Disruption of natural disturbance regimes due to human activities has major consequences for the structure and function of ecosystems (Pickett and White 1985). In mountain big sagebrush (Artemisia tridentata subsp. vaseyana) communities of the sagebrush steppe, decreased fire frequency due to overgrazing by livestock and suppression practices has transformed mosaics of sagebrush and grassland into homogeneous stands of sagebrush and contributed to the rapid expansion of juniper woodlands (Burkhardt and Tisdale 1976, Miller et al. 1994). Prior to European settlement, fire typically occurred every $15-25$ years in this community (Miller and Rose 1999); recurring fire maintained patches of native grassland and restricted juniper, a fire-intolerant species, to rocky outcrops and shallow-soil benchlands where fire was unlikely to occur (Burkhardt and Tisdale 1976, Miller and Wigand 1994). In the last century, juniper has invaded large areas of mountain big sagebrush and continues to increase in density and extent in the absence of fire (Burkhardt and Tisdale 1976, Miller and Rose 1999). Many bird species associated with the sagebrush steppe now exhibit population declines across their range due to habitat loss and fragmentation (Saab and Rich 1997, Paige and Ritter 1999). Fire influences habitat availability and configuration at multiple scales and negatively affects sagebrush-obligate birds (Tiagwad et al. 1982, Bock and Bock 1987, Knick and Rotenberry 1995, Connelly et al. 2000). However, results among studies of birdhabitat relationships in sagebrush communities are inconsistent for many species, possibly due to differences in landscape context and local bird populations (Petersen and Best 1987, Knick and Rotenberry 1995). Variation among natural fire regimes associated with different sagebrush communities might also contribute to differences among previous avian studies. In low-elevation (usually < $1500 \mathrm{~m}$ ) sagebrush communities (e.g., A. tridentata subsp. wyomingensis), fires were historically infrequent because low precipitation levels limited fuel

\footnotetext{
${ }^{1}$ Department of Fisheries and Wildlife, Oregon State University, Corvallis, OR 97331.

2Eastern Oregon Agricultural Research Center, HC 71 4.51 Hwy 205, Burns, OR 97720.

3Present address: Avian Science Center, Division of Biological Sciences, University of Montana, Missoula, MT 59812. E-mail: anna.noson@umontana.edu
} 
accumulations (Whisenant 1990, Miller et al. 1998). At higher elevations, sagebrush communities dominated by mountain big sagebrush are typically more productive (i.e., accumulate more fuels); hence, they burned more frequently (Miller et al. 1998). Juniper encroachment is also occurring primarily in the more mesic high-elevation sagebrush communities. The encroachment of juniper represents a major change in the structure of sagebrush habitat that has potential consequences for obligate species (Reinkensmeyer 2000, Rosenstock and Van Riper III 2001). Without periodic fire, juniper density increases, resulting in subsequent loss of sagebrush to as low as $<1 \%$ of historic cover (Miller et al. 2000). Once sagebrush cover declines, there is little groundlevel fuel available to carry fire, and juniper habitat becomes increasingly less susceptible to burning (Bunting 1987, Miller et al. 2000). This suggests that, whereas mountain big sagebrush communities are adapted to frequent fire and recover quickly after disturbance, the permanence of juniper encroachment may inflict a more lasting impact on sagebrush birds in this community.

Recent research has focused on altered fire regimes in low-elevation sagebrush communities suffering rapid and potentially irreversible conversion to agriculture and exotic grasslands (Knick and Rotenberry 1995, Vander Haegen et al. 2000). These areas represent a major portion of the sagebrush steppe. However, highelevation sagebrush communities are still comparatively intact, and therefore may represent vital reproductive habitat for sagebrush obligates. Furthermore, there is evidence that mountain big sagebrush supports higher bird abundance and species richness than lower elevation sagebrush communities (Medin et al. 2000, Vander Haegen et al. 2000). Prescribed fire is the primary management tool used to restore high-elevation sagebrush communities (Clark and Starkey 1990). Yet the influence of fire on birds in mountain big sagebrush has received little attention. Our objective was to quantify relationships between sagebrushassociated birds and a mountain big sagebrush community influenced by prescribed fire and by juniper invasion due to lack of fire. To this end, we tested the relative importance of sagebrush habitat and juniper encroachment at 2 spatial scales on bird abundance and occurrence using a nested, multiscale analysis. Our goal was to provide guidance for the use of fire in the management of high-elevation sagebrush bird communities.

\section{Study Area}

The study was conducted on Steens Mountain, an isolated fault-block escarpment in southeastern Oregon. The climate in this region is cool and semiarid (Hansen 1956). Annual precipitation ranges from $25 \mathrm{~cm}$ at the base to almost $36 \mathrm{~cm}$ at higher elevations and falls mainly during winter.

Mountain big sagebrush is the dominant vegetation community on Steens Mountain above 1500 m elevation. Low sagebrush (Artemisia arbuscula) occurs in patches of shallow soils and ridge tops. Other common shrubs include mountain snowberry (Symphoricarpos oreophilus), gray rabbitbrush (Chrysothamnus nauseous), and green rabbitbrush (C. viscidiflorus). The understory is characterized by bunchgrasses, including bluebunch wheatgrass (Agropyron spicatum), Idaho fescue (Festuca idahoensis), and Sandberg's bluegrass (Poa sandbergii). Common forbs include lupine (Lupinus spp.) and paintbrush (Castilleja spp.). Isolated aspen (Populus tremuloides) stands form narrow bands along north-facing aspects, and western juniper woodlands stretch discontinuously between $1450 \mathrm{~m}$ and $2100 \mathrm{~m}$ (Miller and Rose 1995). Western juniper is rapidly invading sagebrush, aspen, and riparian communities on Steens Mountain. This pattern is similar to juniper woodland expansion throughout the western United States (Miller and Rose 1995, Miller and Rose 1999, Miller and Tausch 2001). We centered the study area on a prescribed fire conducted in fall 1999 by the Bureau of Land Management (BLM). The study area extended across 7694 ha from $1878 \mathrm{~m}$ to $2319 \mathrm{~m}$ in elevation and contained a mosaic of burned and unburned vegetation communities with a total of 2464 burned hectares. Prior to the 1999 fire, the study area had not burned for over 25 years.

\section{Methods}

\section{Bird Surveys}

Bird counts were conducted during the 2000 breeding season at 172 survey points that encompassed varying amounts and configurations of burned and unburned sagebrush and 
juniper densities. We generated a randomized, systematic grid of survey points in a geographic information system (GIS), using a random number generator to select coordinates for a point of origin within the study area. Survey points were located $500 \mathrm{~m}$ apart to ensure independence of bird detections (Ralph et al. 1993). Unlike mixed juniper and sagebrush communities, aspen represents a distinct habitat that supports a different bird community. To focus on sagebrush-associated birds we restricted sampling to $>100 \mathrm{~m}$ from aspen patches.

Each point was surveyed between 1 June and 27 June 2000 using a fixed-radius point count method (Ralph et al.1993). After waiting at least 2 minutes after arrival at a point, we recorded the presence of all birds seen or heard within $100 \mathrm{~m}$ during a 5-minute interval. Surveys were limited to the 4 hours following sunrise on mornings with little wind $\left(<15 \mathrm{~km} \cdot \mathrm{h}^{-1}\right)$ and no precipitation. Since the purpose of this study was to investigate landscape-level bird-habitat relationships, we collected point count data only once during the breeding season to maximize the number of sites that could be surveyed across the landscape (Knick and Rotenberry 1995).

\section{Habitat Measures}

Local habitat characteristics were measured at each bird survey point during June and July 2000 (Table 1). Two parallel 200-m transects were positioned at $25 \mathrm{~m}$ on either side of the point and were oriented along the same random compass bearing. We measured the proportion of each transect that was burned. Percent grass cover and shrub cover by species were estimated along transects using the lineintercept method (Canfield 1941). For each transect we also measured average sagebrush height. An index of sagebrush patchiness was calculated as the number of times transects crossed from mountain big sagebrush to another vegetation community. Juniper density was obtained from counts of trees $>1 \mathrm{~m}$ in height within a $100-\mathrm{m}$ radius of the point.

We used Landsat Thematic Mapper (TM) satellite images and aerial photographs to develop a GIS map of major cover types for the study area. All images were spatially registered and corrected for geometric distortion (ERDAS 1999). Deciduous vegetation was classified from a satellite image taken 4 September
1999 using supervised classification methods and a maximum likelihood algorithm (ERDAS 1999). For classification of burned areas, we used the 1st satellite image available following the prescribed fire (20 October 1999) and digitized aerial photographs (scale 1:24,000) taken in August 2000. We combined vegetation and burn coverages to create a single map of major cover types that corresponded with our localscale habitat measures. Major cover types used in analysis were (1) burn, (2) sagebrush, and (3) juniper. Aspen and willow riparian / wet meadow cover types were also used for calculation of some landscape metrics. Resolution of the map was $25 \mathrm{~m}^{2}$ (resampled from $30-\mathrm{m}^{2}$ pixel cells in the original Landsat TM images); therefore, $25 \mathrm{~m}^{2}$ represented the smallest possible habitat patch. We assessed the accuracy of the derived cover type map with groundtruthed data not used for classification. The Kappa coefficient for overall accuracy was $80.16 \%$, which included the errors of omission and commission and accounted for agreement expected to occur by chance alone (Congalton 1991).

We used the spatial analysis program Patch Analyst (Elkie et al. 1999) to calculate landscape metrics from the derived map of cover types within a 1-km radius of each survey point (Table 1). Metrics at this scale were predictive of sagebrush bird occurrence in previous studies (Knick and Rotenberry 1995) and represented an area large enough to describe regional bird distributions. We calculated the percent area of each cover type, the largest patch index for sagebrush (percentage of the landscape composed of the largest patch), and sagebrush edge density (total length of sagebrush edge divided by total area).

\section{Statistical Analysis}

Bird species of conservation concern (Paige and Ritter 1999) breeding in sagebrush steppe and detected at $>10 \%$ of survey points were included in the statistical analysis. The bestapproximating model for each bird species was selected from a single suite of a priori models (Burnham and Anderson 1998). Abundance of common bird species was modeled using Poisson regression (PROC GENMOD, SAS Institute 2000). When birds were rare, measures of abundance at points essentially described a binary response of presence or absence. Therefore, we used logistic regression to model the 
TABLE 1. Summary statistics for local and landscape variables included in analysis. Variables were measured at 172 survey points located on Steens Mountain, Oregon, 2000.

\begin{tabular}{|c|c|c|}
\hline Variables & Description & $\bar{x} \pm s$ \\
\hline \multicolumn{3}{|c|}{ LOCAL SCALE (within 100 m) } \\
\hline SAGECOV & Sagebrush cover $(\%)$ & $6.7 \pm 6.9$ \\
\hline GRASS & Grass cover $(\%)$ & $5.4 \pm 4.5$ \\
\hline HEIGHT & Average height of sagebrush $(\mathrm{cm})$ & $60.3 \pm 18.9$ \\
\hline PATCH & Index of sagebrush patchiness (no.) & $1.6 \pm 1.1$ \\
\hline DJUNP & Density of juniper (trees $\cdot \mathrm{ha}^{-1}$ ) & $10.3 \pm 26.6$ \\
\hline \multicolumn{3}{|c|}{ LANDSCAPE SCALE (within $1 \mathrm{~km}$ ) } \\
\hline $\mathrm{SAGE}_{\text {land }}$ & Sagebrush $(\%)$ & $22.4 \pm 14.1$ \\
\hline $\mathrm{JUNP}_{\text {land }}$ & Juniper $(\%)$ & $9.6 \pm 12.1$ \\
\hline EDGE $_{\text {land }}$ & Edge density of sagebrush $\left(\mathrm{m} \cdot \mathrm{ha}^{-1}\right)$ & $66.6 \pm 18.4$ \\
\hline
\end{tabular}

probability of occurrence of less abundant species (PROC GENMOD, SAS Institute 2000). We measured relative abundance as the total number of detections of a given species at a point and occurrence as 1 or more detections of that species at a point.

Low bird densities in juniper prohibited correcting for detectability by habitat. We examined detections in 10-m distance intervals and found no significant decrease in detections per unit area until $>120 \mathrm{~m}$ for Sage Thrashers and $>60 \mathrm{~m}$ for all other species included in this study. To minimize potential bias in detectability, we restricted analysis to detections within $50 \mathrm{~m}$ for all species except Sage Thrashers. We retained a 100-m radius plot for Sage Thrashers because they typically nest in low densities (Medin 1992), are conspicuous and audible at long distances, and were detected most often at distances $>50 \mathrm{~m}$.

Model Development.-We used a nested, multiscale framework for developing predictive models to (1) examine relationships with sagebrush habitat and habitat fragmentation due to fire found in previous studies and (2) determine the relative importance of juniper encroachment. Prescribed fire influences the availability and structure of habitat, which can in turn affect the distribution and abundance of birds (MacArthur and MacArthur 1961, Cody 1985). To examine this relationship, we developed 17 sagebrush habitat models for individual bird species using local- and landscape-scale measures of habitat structure, composition, and configuration (Table 2). The first 8 models describe potential relationships with sagebrush at the local scale. The remaining 9 models focus on the influence of landscape-scale measures of habitat fragmentation and explore improvements to models made by including measures of local sagebrush habitat. Models without a measure of percent sagebrush cover or containing percent grass cover were targeted at Vesper Sparrows. We considered alternative forms of variables (i.e., squared terms) for species with habitat associations suggesting a nonlinear relationship with specific variables. We determined whether juniper encroachment improved the sagebrush habitat models by adding a measure of juniper at the local or landscape scale to the suite of sagebrush habitat models. We also included a null model with no variables and a global model. For each species, the global model was tested for lack of fit using a drop-in-deviance chi-square test (Ramsey and Schafer 1997).

There was a strong negative correlation between percent cover of sagebrush and burn measured locally $(r=0.71)$. At the landscape scale, percent sagebrush, percent burn, and the largest patch index were all highly correlated $(r>0.78)$. To minimize problems associated with multicollinearity, we only included percent sagebrush cover at the local scale and percent sagebrush in the landscape in the candidate models; we eliminated percent burn at both scales and the largest patch index.

Model SELECTIOn.-The candidate models were ranked by their ability to explain the data using Akaike's Information Criterion modified for small sample size $\left(\mathrm{AIC}_{c}\right.$; Burnham and Anderson 1998):

$$
A I C_{c}=-[2 \log (\mathrm{L}(\theta))]+2 K+\frac{2 K(K+1)}{n-K-1}
$$

where $\log (L(\theta))$ is the natural logarithm of the likelihood function of the model parameters; $K$ is the number of estimable parameters in the model; and $n$ is the sample size. The model $(i)$ 
TABLE 2. Seventeen a priori candidate models relating bird species to sagebrush habitat and habitat fragmentation due to fire on Steens Mountain, Oregon, 2000. Models are organized according to the predictions that guided model development. See Table 1 for a description of variable codes.

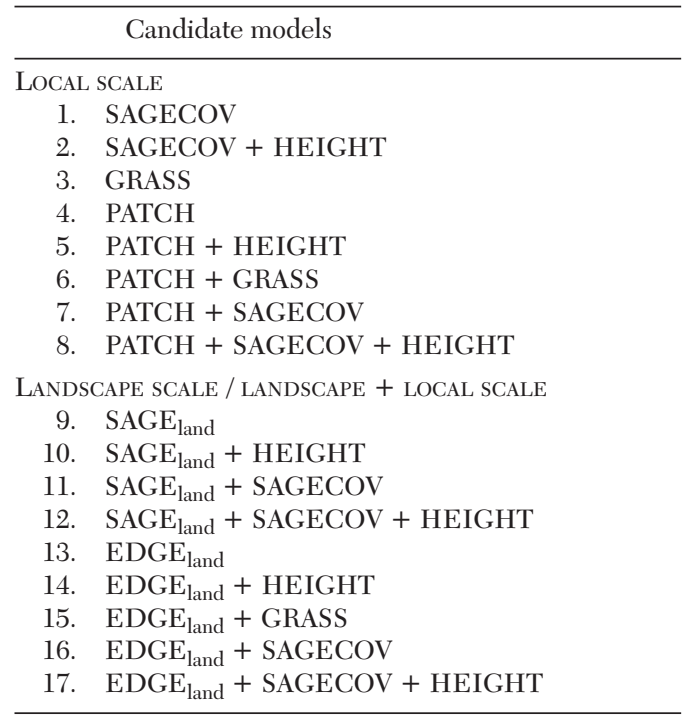

with the minimum $\mathrm{AIC}_{c}$ value was selected as the best-approximating model to the data. We examined the relative importance of juniper encroachment by comparing the best sagebrush habitat model with the best model containing a juniper metric using the $\mathrm{AIC}_{c}$ differences, or $\Delta \mathrm{AIC}_{c}\left(\Delta \mathrm{AIC}_{c}=\mathrm{AIC}_{c i}-\min \mathrm{AIC}_{c}\right)$, of the 2 models. Models with $\Delta \mathrm{AIC}_{c}<2$ were considered equally important (Burnham and Anderson 1998). Variable selection uncertainty and the relative importance of all explanatory variables included in the suite of models $(r)$ were assessed by summing the Akaike weights $\left(w_{i}\right)$ of each model that contained the variable (Burnham and Anderson 1998). We calculated the Akaike weight $\left(w_{i}\right)$ for each model as:

$$
w_{i}=\frac{\exp \left(-0.5\left[\mathrm{AIC}_{c i}-\min \left(\mathrm{AIC}_{c r}\right)\right]\right)}{\sum_{r=1} \exp \left(-0.5\left[\mathrm{AIC}_{c r}-\min \left(\mathrm{AIC}_{c r}\right)\right]\right)}
$$

\section{RESUlTS}

\section{Habitat Characteristics}

The prescribed fire burned unevenly, creating a mosaic of burned and unburned sagebrush and a wide range of sagebrush patch sizes (Table 1). Within burned patches, almost all vegetation was consumed by fire. Average shrub cover $( \pm s)$ in unburned areas was $13.0 \%$ $\pm 6.7 \%$, while in burned areas average shrub cover was only $2.2 \% \pm 2.4 \%$, and was primarily made up of new growth.

Juniper density at sites ranged from 0 to 117 trees $\cdot$ ha $^{-1}$, with most sites in the early stages of juniper woodland development $(<50$ trees $\cdot \mathrm{ha}^{-1}$; Miller and Rose 1995). The percent cover of juniper within $1 \mathrm{~km}$ of sites ranged from $<1 \%$ to $>66 \%$.

\section{Bird Assemblage}

During summer 2000, observers recorded 1525 individuals representing 49 bird species at the survey points. We concentrated our analysis on Brewer's Sparrows, Sage Thrashers, Green-tailed Towhees, and Vesper Sparrows and modeled the probability of occurrence for all 4 species. Brewer's Sparrows and Vesper Sparrows were the 2 most common species and together made up over $50 \%$ of the total detections. This abundance permitted analysis of relative abundance for these 2 species.

\section{Habitat Models}

Including a measure of juniper encroachment substantially improved models for all species in the analysis $\left(\Delta \mathrm{AIC}_{c}>12.56\right.$; Table 3 ). Percent juniper cover in the landscape was relatively more important than local juniper density for most species (Table 4). Most species included in this study were also positively associated with local sagebrush cover and sagebrush height, although the relative importance of these variables varied by species (Table 4). Sagebrush habitat fragmentation (e.g., local sagebrush patchiness, sagebrush edge density, or percent sagebrush in the landscape) contributed considerably to models for 3 species.

ABUNDANCE MODELS.-The $\mathrm{AIC}_{c}$-selected best model predicting Brewer's Sparrow abundance included a positive relationship with percent sagebrush cover and sagebrush edge density in the landscape but a negative relationship with percent juniper in the landscape (Table 3; Fig. 1a). Sagebrush height also appeared to be relatively important based on Akaike weights (Table 4).

Vesper Sparrows were more abundant at sites with higher sagebrush patchiness and in landscapes with lower percent juniper, based on the best-approximating model (Table 3; 
TABLE 3. Best approximating sagebrush and sagebrush + juniper models (i.e., models with lowest Akaike Information Criterion corrected for small sample sizes $\left[\mathrm{AIC}_{c}\right]$ ) for bird species abundance and occurrence on Steens Mountain, Oregon, 2000.

\begin{tabular}{|c|c|c|}
\hline Species and model type & $\Delta \mathrm{AIC}_{c}^{\dagger}$ & Best models $\ddagger$ \\
\hline \multicolumn{3}{|l|}{ ABUNDANCE } \\
\hline \multicolumn{3}{|l|}{ Brewer's Sparrow } \\
\hline Sagebrush & 35.53 & $-0.742+0.028($ SAGECOV $)+0.007($ HEIGHT $)+0.113\left(\right.$ EDGE $\left._{\text {land }}\right)$ \\
\hline Sagebrush + Juniper & 0.00 & $-0.1045+0.038($ SAGECOV $)+0.013\left(\mathrm{EDGE}_{\text {land }}\right)-0.047\left(\mathrm{JUNP}_{\text {land }}\right)$ \\
\hline \multicolumn{3}{|l|}{ Vesper Sparrow } \\
\hline Sagebrush & 28.54 & $-0.732+0.214(\mathrm{PATCH})$ \\
\hline Sagebrush + Juniper & 0.00 & $-0.199+0.233(\mathrm{PATCH})-0.093\left(\mathrm{JUNP}_{\text {land }}\right)$ \\
\hline \multicolumn{3}{|l|}{ OCCURRENCE } \\
\hline \multicolumn{3}{|l|}{ Vesper Sparrow } \\
\hline Sagebrush & 26.77 & $-1.77+0.023\left(\mathrm{EDGE}_{\text {land }}\right)$ \\
\hline Sagebrush + Juniper & 0.00 & $-1.039+0.025\left(\mathrm{EDGE}_{\text {land }}\right)-0.126\left(\mathrm{JUNP}_{\text {land }}\right)$ \\
\hline \multicolumn{3}{|l|}{ Sage Thrasher } \\
\hline Sagebrush & 12.56 & $-1.841+0.038\left(\mathrm{SAGE}_{\text {land }}\right)$ \\
\hline Sagebrush + Juniper & 0.00 & $-0.9762+0.060($ SAGECOV $)-0.103(\mathrm{DJUNP})$ \\
\hline \multicolumn{3}{|l|}{ Green-tailed Towhee } \\
\hline Sagebrush & 16.91 & $-3.175+\left(\mathrm{SAGE}_{\text {land }}\right)+0.027(\mathrm{HEIGHT})$ \\
\hline Sagebrush + Juniper & 0.00 & $-3.455+0.046\left(\mathrm{SAGE}_{\text {land }}\right)+0.189\left(\mathrm{JUNP}_{\text {land }}\right)-0.003\left(\mathrm{JUNP}_{\text {land }}\right)^{2}$ \\
\hline
\end{tabular}

Fig. 1b). Several additional measures of local sagebrush habitat were somewhat important, including sagebrush height and sagebrush cover (Table 4).

OCCURRENCE MODELS.-Brewer's Sparrows were detected at 129 survey points. The global model outperformed all other candidate models considered for Brewer's Sparrow occurrence; therefore, the suite of models was considered a poor fit and none were selected. This is not surprising since Brewer's Sparrows occurred on nearly every site surveyed. We observed Vesper Sparrows at 75 survey points. Vesper Sparrows were more likely to occur in landscapes with high sagebrush edge density and low percent juniper (Table 3; Fig. 2a). Again, there was some suggestion that other local-scale measures of sagebrush habitat may also be important, particularly sagebrush patchiness (Table 4).

We detected Sage Thrashers at 48 survey points. The best-approximating model predicted that Sage Thrashers would occur more frequently at sites with greater sagebrush cover and lower juniper density (Table 3; Fig. 2b). Sagebrush height, and, in the landscape, sagebrush edge density and percent juniper cover were also moderately important based on Akaike weights (Table 4).

Green-tailed Towhees were detected at 42 points. We included a quadratic form for DJUNP and JUNP ${ }_{\text {and }}$ in the suite of candidate models considered for Green-tailed Towhees based on findings from previous studies and the fit of the global model (Table 1; Knopf et al. 1990, Franklin et al. 2000). Green-tailed Towhees were predicted to occur more often in landscapes with greater percent sagebrush. The best-approximating model also predicted a curvilinear relationship with percent juniper in the landscape, such that the probability of occurrence peaked at approximately $33 \%$ and then declined with increasing juniper (Table 3; Fig. 2c). Based on Akaike weights, the variables included in the best model were considerably more important than all other variables; however, local-scale sagebrush cover, sagebrush height, and juniper density were also moderately important (Table 4).

\section{Discussion}

As predicted, local-scale sagebrush characteristics were particularly important to the 2 sagebrush obligates included in this study (e.g., Brewer's Sparrows and Sage Thrashers). The relationship of these species to sagebrush cover, and in the case of Brewer's Sparrows, sagebrush height, is well documented in previous research (Wiens and Rotenberry 1981, Knopf et al. 1990, Knick and Rotenberry 1995). Because fire typically removes most of the shrub layer in this system, our results indicate 
that burning will have a negative effect on these bird species at the local scale.

Similar to previous studies in low-elevation sagebrush communities, all the species in this study showed sensitivity to sagebrush fragmentation in the landscape (Knick and Rotenberry 1995, Vander Haegen et al. 2000). The Greentailed Towhee, termed a "near-obligate" (Braun et al. 1976), was more likely to occur in landscapes with more sagebrush. Though relatively less important than other factors, a similar relationship existed between Sage Thrashers and amount of sagebrush in the landscape. Since percent sagebrush and percent burn were highly correlated in our study, this also describes a negative relationship with landscape-scale fire disturbance. In southeastern Idaho, Sage Thrashers also occurred more often in areas with higher spatial similarity of habitat within $1 \mathrm{~km}$ (Knick and Rotenberry 1995). The Vesper Sparrow, often considered a grassland species, was more abundant in sites with patchy sagebrush and more likely to occur in landscapes with higher sagebrush edge density -2 conditions created by fire. High Vesper Sparrow densities have been recorded in recent burns (Petersen and Best 1987, Reinkensmeyer 2000). However, others have found positive associations between Vesper Sparrow abundance and shrub cover (Wiens and Rotenberry 1981, Vander Haegen et al. 2000). Interestingly, abundance of Brewer's Sparrows in our study, while positively associated with sagebrush cover at a local scale, was also positively related to sagebrush edge density in the surrounding landscape. This is contrary to the findings of Knick and Rotenberry (1995) who reported Brewer's Sparrows occurring more often in larger sagebrush patches. Sage Thrashers also showed a positive, though weak, relationship with sagebrush edge density. Unlike sagebrush communities at lower elevations, high-elevation sagebrush communities were naturally fragmented by frequent fire (Miller and Rose 1999). The different responses of sagebrush obligates to landscapescale habitat fragmentation may be related to differences in the disturbance regimes among sagebrush communities and warrant further investigation.

Although sagebrush habitat and habitat fragmentation associated with fire influenced the abundance and occurrence of bird species in this study, including a measure of juniper 

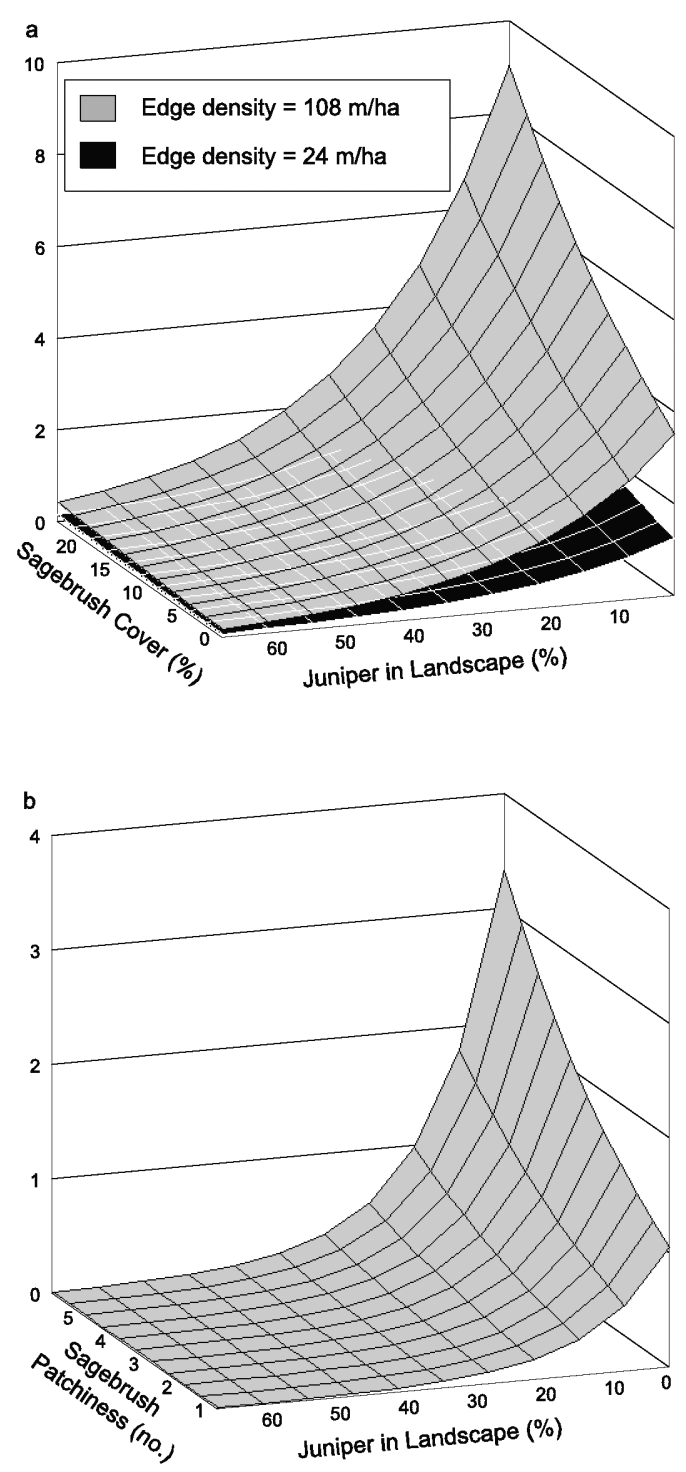

Fig. 1. Best approximating model (i.e., model with lowest Akaike Information Criterion corrected for small sample sizes $\left[\mathrm{AIC}_{c}\right]$ ) predicting relative abundance (y-axis) of (a) Brewer's Sparrows, and (b) Vesper Sparrows on Steens Mountain, Oregon, 2000. Values on the horizontal axes were limited to the range observed on sites (note: maximum and minimum recorded values are shown as separate surfaces for models containing 3 variables).

encroachment substantially improved all models. Brewer's Sparrows and Vesper Sparrows were negatively associated with the amount of juniper in the landscape, and Sage Thrashers were less likely to occur at sites with even a few juniper. Green-tailed Towhees had a more complex relationship with juniper, prefer- ring landscapes with a moderate percentage of juniper. Previous studies have also detected fewer shrub- and grassland-nesting birds in sagebrush with juniper than without juniper (Maser et al. 1984, Rosenstock and Van Riper 2001). Reinkensmeyer (2000) detected significantly higher Brewer's Sparrow and Sage Thrasher densities in sagebrush than in midand late-successional juniper woodlands. However, the relationship between Green-tailed Towhees and juniper is not consistent across previous studies. Reinkensmeyer (2000) detected more Green-tailed Towhees in areas with no juniper than in either early or latesuccessional juniper woodland, whereas a regional study by Knopf et al. (1990) indicated that Green-tailed Towhees most often occur at ecotones between sagebrush and other large shrub or tree communities.

Juniper encroachment results in a loss of sagebrush cover (Bunting 1987, Miller et al. 2000), which may explain the eventual decrease in predicted Green-tailed Towhee occurrence with high amounts of juniper in the landscape. Even at low density, junipers support avifauna that may compete with sagebrush birds (Blair 1996). In central Oregon, Reinkensmeyer (2000) detected significantly more Brown-headed Cowbirds (Molothrus ater) in sagebrush communities with juniper, exposing birds to more potential parasitism. Parasitism rates by Brownheaded Cowbirds generally appear low for Brewer's Sparrows and Vesper Sparrows (Vander Haegen and Walker 1999) but are not well documented for Sage Thrashers.

Bird populations in sagebrush steppe are often highly variable across time and space (Wiens and Rotenberry 1981). This variation may have influenced our findings, given that our results are from a single year. However, our habitat models were largely consistent with habitat associations previously described for these species (Knick and Rotenberry 1995, Vander Haegen et al. 2000). In addition, multiyear studies have found links between temporal persistence of sagebrush obligates and habitat conditions that are similar to habitat associations we found after a single year on Steens Mountain (Knick and Rotenberry 1995).

This study was conducted across the only fire that occurred in the region in a high-elevation mountain big sagebrush and juniper community in 1999. We believe the study area 

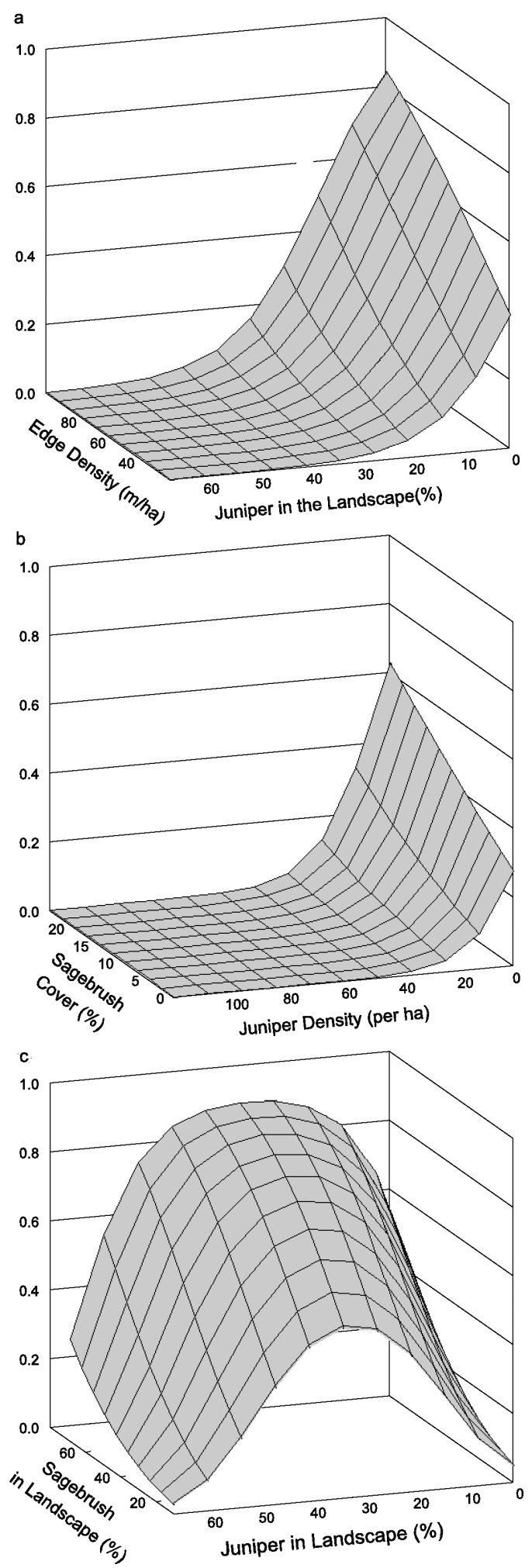

is representative of the region because it encompasses a large area and because sites represented a wide range in habitat characteristics. However, further research targeted at bird communities in high-elevation sagebrush communities is needed to determine the influence of fire and juniper across this system.

\section{Conclusions and Management RECOMMENDATIONS}

The bird species we examined had distinct relationships with vegetation structure and composition. Vesper Sparrows were associated with patchy, open sagebrush stands, while Brewer's Sparrows and Sage Thrashers were associated with greater sagebrush cover. Greentailed Towhees occurred most often in landscapes of mixed sagebrush and juniper. Since these analyses are based on bird data from a single year, our study can only provide a snapshot of the relationships of bird species to habitat characteristics. However, ecological processes occurring through time shape the variation in habitats present in the landscape. Areas with juniper at low densities represent an early stage in the process of juniper encroachment, whereas areas with juniper at high densities represent late-successional woodlands. Furthermore, burns, sagebrush, and juniper woodlands represent habitats along a gradient from recently burned to increasing time since fire, and individual bird species were variously associated with habitat conditions at different points along this trajectory.

Unlike low-elevation areas where changes in sagebrush communities are associated with greater fire frequency due to the invasion of exotic annual grasses over the last century (Young and Evans 1978, Rotenberry 1998), the absence of fire has changed the structure and function of high-elevation mountain big sagebrush communities adapted to frequent disturbance (Miller and Rose 1999). In the absence of fire, landscape-scale patchiness has

Fig. 2. Best approximating model (i.e., model with lowest Akaike Information Criterion corrected for small sample sizes $\left.\left[\mathrm{AIC}_{c}\right]\right)$ predicting probability of occurrence (yaxis) of (a) Vesper Sparrows, (b) Sage Thrashers, and (c) Green-tailed Towhees on Steens Mountain, Oregon, 2000. Values on the horizontal axes were limited to the range observed on sites. 
declined and fire-intolerant juniper densities have increased. Our models predict that, in addition to the expected relationship with sagebrush habitat, sagebrush-obligate bird species on Steens Mountain are also considerably influenced by juniper encroachment, and these relationships occur at multiple spatial scales.

Any management action that reduces available sagebrush habitat for sagebrush-obligate birds threatened by widespread habitat loss is controversial. However, juniper encroachment may also have major consequences for sagebrush birds. Furthermore, the effects of juniper expansion are potentially long-term. As juniper density increases, sagebrush cover declines until a threshold is crossed and the probability of a fire of sufficient intensity to remove juniper becomes unlikely (Bunting 1987, Miller et al. 2000). There are alternative methods for controlling juniper, such as chaining or cutting, but the most widely accepted approach to ecosystem maintenance is restoring natural ecosystem processes such as fire (Pickett and White 1985, Miller et al. 2000).

The negative effects of fire on sagebrushassociated bird species may be minimized through incomplete burning that resembles the spotty fires that occurred historically (Miller and Rose 1999); these historical fires retained residual unburned sagebrush within burns. In this study Brewer's Sparrows occurred in areas with only a few remaining unburned shrubs and were more abundant in landscapes with greater sagebrush fragmentation. Previous studies have also documented minimal changes in sagebrush-obligate communities with incomplete removal of sagebrush from a site (Tiagwad et al. 1982, Wiens and Rotenberry 1985, Petersen and Best 1987). Unburned islands of sagebrush may act as refugia, providing a source of sagebrush seeds and the habitat characteristics necessary for associated birds (Smith 2000). Alternatively, birds may be packing into remaining unburned areas following fire, and bird occurrence and abundance are not always indicators of habitat quality (Van Horne 1983). Two things are needed to inform best-management practices in this system: (1) an understanding of the influence of fire and juniper encroachment on the survival and reproductive success of sagebrush birds and (2) further research in high-elevation sagebrush communities.

\section{ACKNOWLEDGMENTS}

This research was funded by Oregon State University and the U.S. Bureau of Land Management, Burns Office. Additional support was provided by the Eastern Oregon Agricultural Research Center. We thank L. Carter and D. Milek for their contribution in the field, and R.W. Baumann, R.T. Hoggan, K.F. Higgins, F. Howe, and an anonymous reviewer for providing valuable comments.

\section{Literature Cited}

BLAIR, R.B. 1996. Land use and avian species diversity along an urban gradient. Ecological Applications 6: 506-509.

Bock, C.E., AND J.H. Bock. 1987. Avian habitat occupancy following fire in a Montana shrubsteppe. Prairie Naturalist 19:153-158.

Braun, C.E., T. Britt, and R.O. Wallestad. 1976. Conservation committee report on effects of alteration of sagebrush on associated avifauna. Wilson Bulletin 88:165-171.

BunTing, S.C. 1987. Use of prescribed burning in juniper and pinyon-juniper woodlands. Pages 141-144 in R.L. Everett, editor, Proceedings of the Pinyon Juniper Conference. USDA Forest Service, General Technical Report INT-GTR-215.

BurkhardT, J.W., AND E.W. Tisdale. 1976. Causes of juniper invasion in southwestern Idaho. Ecology 76: $472-484$.

Burnham, K.P., AND D.R. Anderson. 1998. Model selection and inference: a practical information-theoretic approach. Springer-Verlag, New York.

CANFIELD, R.H. 1941. Application of the line intercept method in sampling range vegetation. Journal of Forestry 39:386-394.

Clark, R.C., and E.E. Starkey. 1990. Use of prescribed fire in rangeland ecosystems. Pages 81-94 in J.D. Walstad, S.R. Radosevich, and D.V. Sandberg, editors, Natural and prescribed fire in Pacific Northwest forests. Oregon State University Press, Corvallis.

Cody, M.L. 1985. Habitat selection in birds. Academic Press, New York.

Congalton, R. 1991. A review of assessing the accuracy of classifications of remotely sensed data. Remote Sensing of Environment 37:35-46.

Connelly, J.W., K.P. ReEse, R.A. Fisher, AND W.L. WAKKINEN. 2000. Response of a sage grouse breeding population to fire in southeastern Idaho. Wildlife Society Bulletin 28:90-96.

Elkie, P.C., R.S. Rempel, AND A.P. Carr. 1999. Patch analyst user's manual: a tool for quantifying landscape structure. Ontario Ministry of Natural Resources, Technical Manual TM-002.

ERDAS. 1999. ERDAS field guide. 5th edition. ERDAS, Inc., Atlanta, GA.

Franklin, A.B., D.R. Anderson, R.J. Gutierrez, and K.P. Burnham. 2000. Climate, habitat quality, and fitness in Northern Spotted Owl populations in northwestern California. Ecological Monographs 70:539-590. 
Hansen, C.H. 1956. An ecological survey of vertebrate animals on Steens Mountains, Harney County. Doctoral dissertation, Oregon State College, Corvallis.

KNICK, S.T., AND J.T. RotenberRy. 1995. Landscape characteristics of fragmented shrubsteppe habitats and breeding passerine birds. Conservation Biology 9: 1059-1071.

Knopf, F.L., J.A. SEdGwick, And D.B. Inkley. 1990. Regional correspondence among shrubsteppe bird habitats. Condor 92:45-53.

MacArthur, R.H., and J. MacArthur. 1961. On bird species diversity. Ecology 42:594-598.

Maser, C., J.W. Thomas, and R.G. Anderson. 1984. Wildlife habitats in managed rangelands - the Great Basin of southeastern Oregon: the relationship of terrestrial vertebrates to plant communities. USDA Forest Service, General Technical Report RM-GTR-119.

MEDin, D.E. 1992. Birds of a Great Basin sagebrush habitat in west-central Nevada. USDA Forest Service, Research Paper INT-452.

Medin, D.E., B.L. Welch, AND W.P. Clarey. 2000. Bird habitat relationships along a Great Basin elevational gradient. USDA Forest Service, Research Paper RMRS-RP-23.

Miller, R.F., AND J.A. Rose. 1995. Historic expansion of Juniperus occidentalis in southeastern Oregon. Great Basin Naturalist 55:37-45.

1999. Fire history and western juniper (Juniperus occidentalis) encroachment in sagebrush steppe. Journal of Range Management 52:550-559.

Miller, R.F., J.A. Rose, and T. Svejcar. 1998. Fire in the Great Basin. Proceedings of symposium on fire and wildlife in the Pacific Northwest: research, policy, and management, The Wildlife Society, Northwest Section, Spokane, WA.

Miller, R.F., T.J. Svejcar, And J.A. Rose. 2000. Impacts of western juniper on plant community composition and structure. Journal of Range Management 53: $574-585$.

Miller, R.F., and R.J. Tausch. 2001. The role of fire in juniper and pinyon woodlands: a descriptive analysis. Pages 15-30 in K.E.M. Galley and T.P. Wilson, editors, The role of fire in the control and spread of invasive species. Miscellaneous Publication No. 11, Tall Timbers Research Station, Tallahassee, FL.

Miller, R.F., R.J. TAusch, AND N.E. WEST. 1994. Implications of livestock grazing in the intermountain sagebrush region: plant composition. Pages 101-146 in M. Vavra, W.A. Laycock, and R.D. Pieper, editors, Ecological implications of livestock herbivory in the West. Society for Range Management, Denver, CO.

Miller, R.F., AND P.E. Wigand. 1994. Holocene changes in semiarid pinyon-juniper woodlands. Bioscience 44:465-474.

Paige, C., And S.A. Ritter. 1999. Birds in a sagebrush sea. Partners in Flight, Boise, ID.

Petersen, K.L., AND L.B. Best. 1987. Effects of prescribed burning on nongame birds in a sagebrush community. Wildlife Society Bulletin 15:317-329.

Pickett, S.T.A., AND P.S. White. 1985. The ecology of natural disturbance and patch dynamics. Academic Press, New York.

Ralph, C.J., G.R. Geupel, P. Pyle, T.E. Martin, and D.F. DESAnte. 1993. Handbook of field methods for monitoring landbirds. USDA Forest Service, General Technical Report PSW-GTR-144.
Ramsey, F.L., AND D.W. Schafer. 1997. The statistical sleuth: a course in methods of data analysis. Duxbury Press, Belmont, CA.

Reinkensmeyer, D.P. 2000. Habitat associations of bird communities in shrub-steppe and western juniper woodlands. Master's thesis, Oregon State University, Corvallis.

Rosenstock, S.S., And C. VAN Riper III. 2001. Breeding bird responses to juniper woodland expansion. Journal of Range Management 54:226-232.

RotenberRY, J.T. 1998. Avian conservation research needs in western shrublands: exotic invaders and the alteration of ecosystem processes. In J.M. Marzluff and R. Sallabanks, editors, Avian conservation: research and management. Island Press, Washington DC.

SAAB, V.A., AND T.D. RICH. 1997. Large-scale conservation for neotropical migratory land birds in the interior Columbia Basin. USDA Forest Service, General Technical Report PNW-GTR-399.

SAS InSTITUTE. 2000. SAS/STAT user's guide. Version 8.1. SAS Statistical Institute, Cary, NC.

SмITH, J.K. 2000. Wildland fire in ecosystems: effects of fire on fauna. USDA Forest Service, General Technical Report RMRS-GTR-42. Volume 1.

Tiagwad, T.E., C.M. Olson, and R.E. Martin. 1982. Single-year response of breeding bird populations to fire in a curlleaf mountain mahogany-big sagebrush community. Pages 101-110 in E.E. Starkey, J.F. Franklin, and J.W. Mathews, editors, Ecological research in national parks of the Pacific Northwest. Oregon State University, Corvallis.

Vander Haegen, W.M., F.C. Dobler, and D.J. Pierce. 2000. Shrubsteppe bird response to habitat and landscape variables in Eastern Washington. Conservation Biology 14:1145-1160.

Vander Haegen, W.M., and B. Walker. 1999. Parasitism by Brown-headed Cowbirds (Molothrus ater) in the shrubsteppe of eastern Washington. Pages 34-40 in M.L. Morrison, L.S. Hall, S.K. Robinson, S.I. Rothstein, D.C. Hahn, and T.D. Rich, editors, Proceedings of symposium on research and management of the Brown-headed Cowbird in western landscapes. Studies in Avian Biology No.18.

Van Horne, B. 1983. Density as a misleading indicator of habitat quality. Journal of Wildlife Management 47: 893-901.

Whisenant, S.G. 1990. Changing fire frequencies on Idaho's Snake River plains: ecological and management implications. USDA Forest Service, General Technical Report INT-GTR-276.

Wiens, J.A., AND J.T. Rotenberry. 1981. Habitat associations and community structure of birds in shrubsteppe environments. Ecological Monographs 51:2141.

1985. Response of breeding passerine birds to rangeland alteration in a North American shrubsteppe locality. Journal of Applied Ecology 22:655-668.

YounG, J.A., AND R.A. Evans. 1978. Population dynamics after wildfires in sagebrush grasslands. Journal of Range Management 31:283-289.

Received 2 February 2005 Accepted 16 December 2005 